\title{
Penafsiran Warna-Warna Tradisional Bali dalam Buku Autobiografi Seniman I Made Ada dan Made Wianta Melalui Pendekatan Hermeneutika
}

\author{
Asthararianty \\ Program Studi Desain Komunikasi Visual, Fakultas Seni dan Desain, Universitas Kristen Petra \\ Jalan Siwalankerto 121-131, Surabaya \\ Email: astha@peter.petra.ac.id
}

\begin{abstract}
Abstrak
Penggunaan warna yang terjadi pada beberapa budaya yaitu terlihat pada budaya Bali, budaya Jawa, budaya Minangkabau dan beberapa tempat sekitar pulau Bali. Warna-warna ini menjadi suatu warna yang menyatakan daerahnya masing-masing, menjadikan warna yang ada adalah sebuah warna tradisional bagi mereka. Warna-warna ini tentunya bersinggungan dengan budaya dari asal daerah masing-masing. Dalam perkembangannya, setiap daerah beserta budayanya memiliki seperangkat medianya masing-masing dalam mempertunjukkan kekayaan warnanya. Baik itu dalam bentuk kesenian tradisional seperti wayang, ataupun tari dengan keindahan pakaiannya yang memberikan ciri khas dari daerahnya masing-masing. Demikian juga kesenian yang berasal dari Bali yang nampak identiknya pada hasil-hasil karyanya yang indah, menarik dan sangat diminati. Berdasar dari perkembangan ini, maka bagaimanakah kedudukan warna-warna tradisional tersebut di era modern saat ini khususnya di Bali? Bagaimana kedudukan warna-warna tradisional itu di mata beberapa seniman asli Bali terhadap buku-buku yang isinya adalah mengenai diri mereka sendiri? Masalah ini dilihat berdasarkan sebuah penafsiran mengacu pada teori yang telah ada terhadap buku-buku yang mengabadikan karya sekaligus dirinya masing-masing dalam berkarya.
\end{abstract}

Kata kunci: Warna tradisional, warna Bali.

\begin{abstract}
The use of color that occurs in some cultures is seen in Balinese, Javanese, and Minangkabau cultures, as well as a few places around the island. These colors state their respective regions, making them the region's traditional color. These colors must intersect with the culture of origin of each area. In the process, each region and its culture each has a set of media in demonstrating their color richness. Be it in the form of traditional arts, such as puppet, or dance with the beauty of the clothes, they give the hallmark of their respective regions. Likewise, art from Bali which appears identical to the results of their work is beautiful, interesting and very attractive. Based on this development, then how is the position of the traditional colors in this modern era, especially in Bali? How is the position of the traditional colors in the eyes of some Balinese artists to books which the contents are about themselves? This problem is seen through an interpretation by referring to existing theories of the books that perpetuate each artist's work and themselves at work.
\end{abstract}

Keywords: Traditional color, the color of Bali.

\section{Pendahuluan}

Warna merupakan suatu hal yang sangat menakjubkan. Warna hidup di sekitar kita, baik di alam ataupun benda-benda yang biasa kita pakai. Warna memiliki banyak sekali macam warnanya. Warna dipakai hampir di seluruh aspek kehidupan manusia. Berdasarkan asalnya, warna terbagi menjadi dua macam. Warna yang berasal dari cahaya dan juga warna yang berasal dari bahan buatan atau pigmen.
Dalam bukunya, Darmaprawira (2002) mengatakan bahwa warna dimulai dari zaman dahulu namun baru berkembang menjadi suatu ilmu pengetahuan dalam kurun waktu kemudian. Menurut ilmuwan fisika, warna bersumber dari cahaya. Dikatakan juga bahwa beberapa tokoh di Yunani Kuno pun sempat menyinggung tentang warna. Hingga sampai pada akhirnya Newton menemukan 7 warna pelangi yang disebut dengan spektrum warna. Newton pun diklaim sebagai penelur teori lingkaran warna pertama karena 
penemuannya ini. Tokoh setelahnya adalah J. C. Le Blon yang berhasil menemukan 3 warna utama yakni merah-kuning-biru.

Teori warna berkembang sedemikian rupa dengan beberapa tokoh yang terus menggali warna. Sampai pada teori yang umum atau sering digunakan adalah teori warna Munsell. Munsell dalam buku Darmaprawira (2002) dikatakan telah membuat lingkaran warna menurut dari hasil penelitian ilmuwan fisika, dimana Munsell membuat lingkarannya berbeda dari tokoh-tokoh sebelumnya. Bila warna pokok dalam lingkaran warna sebelumnya segitiga sama sisi, maka warna pokok dalam lingkaran Munsell jarak-jaraknya tidak membentuk segitiga sama sisi kembali.

Keberanekaragaman warna yang muncul, menyebabkan penggunaannya menelurkan kebijakankebijakan tertentu baik terhadap penggunaan terhadap suatu objek ataupun pemaknaannya. Darmaprawira (2002) berkata bahwa macammacam individu ataupun budaya memiliki kriterianya masing-masing yang tentunya berbeda satu dengan lainnya dalam penentuan dan pemakaian warna yang baik dan tepat.

Penggunaan warna yang pada masa lalunya ditentukan oleh beberapa hal yang berkaitan dengan nilai-nilai simbolis namun kini sepertinya lebih mengedepankan pada dasar hal-hal yang berkaitan dengan psikologis. Penggunaan warna yang masih bersinggungan dengan nilai-nilai simbolisnya terjadi dalam beberapa budaya dengan masih dikaitkan pada suatu perlambangan tertentu. Hal ini tidak juga menghilangkan dari segi visualnya yang masih memiliki kaidah estetika yang memukau. Seperti contoh pada beberapa kain yang ada di Indonesia, seperti kain gringsing dari Bali, juga kain ulos ragidup dari Batak.

Penggunaan warna yang terjadi pada beberapa budaya yaitu terlihat pada budaya Bali, budaya Jawa, budaya Minangkabau dan beberapa tempat sekitar pulau Bali. Warna-warna ini menjadi suatu warna yang menyatakan daerahnya masingmasing, menjadikan warna yang ada adalah sebuah warna tradisional bagi mereka. Warnawarna ini tentunya bersinggungan dengan budaya dari asal daerah masing-masing.

Dalam perkembangannya, setiap daerah beserta budayanya memiliki seperangkat medianya masingmasing dalam mempertunjukkan kekayaan warnanya. Baik itu dalam bentuk kesenian tradisional seperti wayang, ataupun tari dengan keindahan pakaiannya yang memberikan ciri khas dari daerahnya masing-masing. Demikian juga keseni- an yang berasal dari Bali yang Nampak identiknya pada hasil-hasil karyanya yang indah, menarik dan sangat dimintai.

Berdasar dari perkembangan ini, maka artikel ini bertujuan untuk mendeskripsikan bagaimanakah kedudukan warna-warna tradisional tersebut di era modern saat ini khususnya di Bali? Bagaimana kedudukan warna-warna tradisional itu di mata beberapa seniman asli Bali terhadap bukubuku yang isinya adalah mengenai diri mereka sendiri? Masalah ini dilihat berdasarkan sebuah penafsiran yang mengacu pada buku autobiografi seniman Bali.

Masalah yang muncul adalah bagaimana hubungan antara budaya yang terjadi dari dulu (masa lampau) hingga sekarang yang berpengaruh dalam warna-warna tradisional di Bali yang saat ini bila dikaitkan dengan penggunaan warna tersebut oleh beberapa seniman asli Bali dalam buku yang berisi tentang seputar diri seniman itu sendiri.

Mengetahui jawaban dari masalah yang muncul tersebut akan mampu memberikan sebuah kejelasan apakah budaya yang berpengaruh dalam warna-warna tradisional Bali juga berpengaruh dalam pembuatan buku tentang diri seniman asli Bali tersebut.

\section{Data dan Hasil Survei}

\section{Buku Autobiografi I Made Ada}

Buku Autobiografi I Made Ada ini memiliki tiga bagian dalam bukunya. Dimana bagian pertama dan kedua memakai warna hitam dan putih. Sedangkan warna pada bagian ke tiga adalah warna emas. Buku Autobiografi I Made Ada ini menampilkan kesan perpaduan antara modern dengan tradisional dimana penggambaran kesan tradisionalnya lebih kental pada warna yang dipakai yakni hitam, putih, emas dan merah maroon.
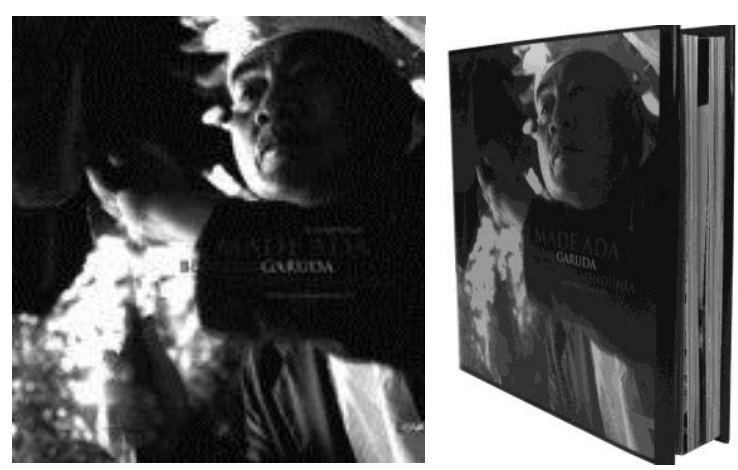

Gambar 1. Cover Buku "I Made Ada" 

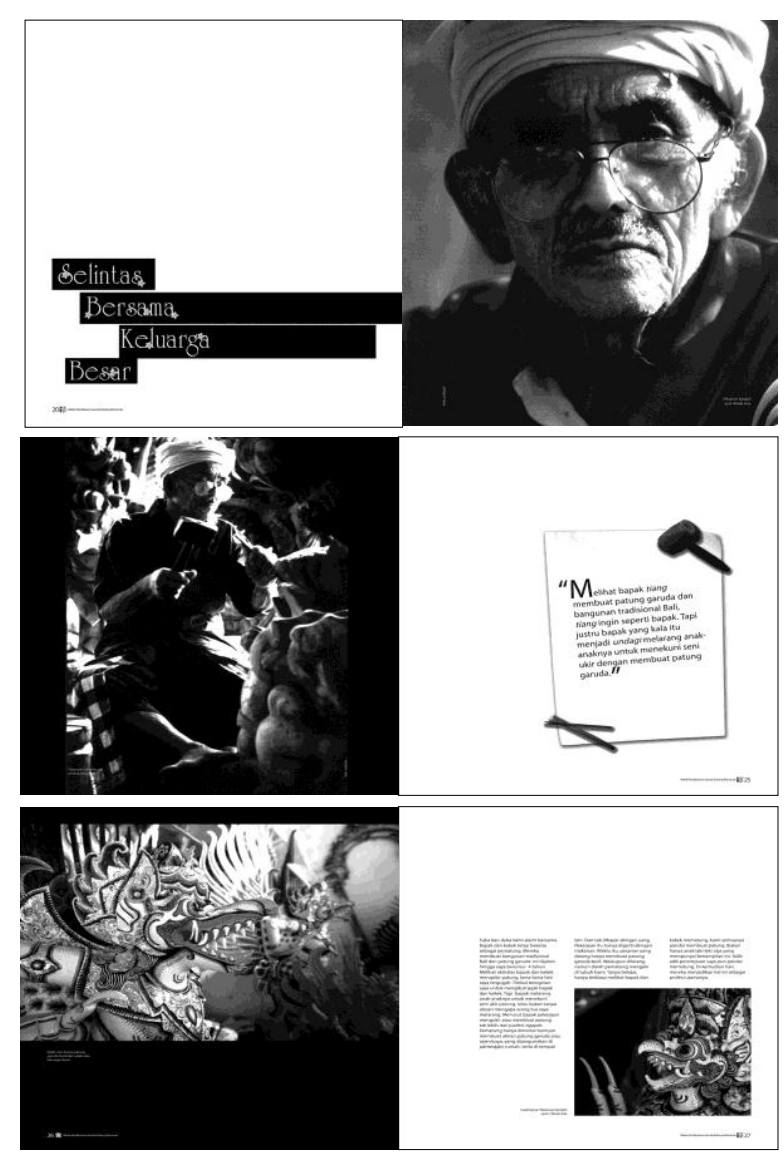

Gambar 2. Halaman isi bagian satu
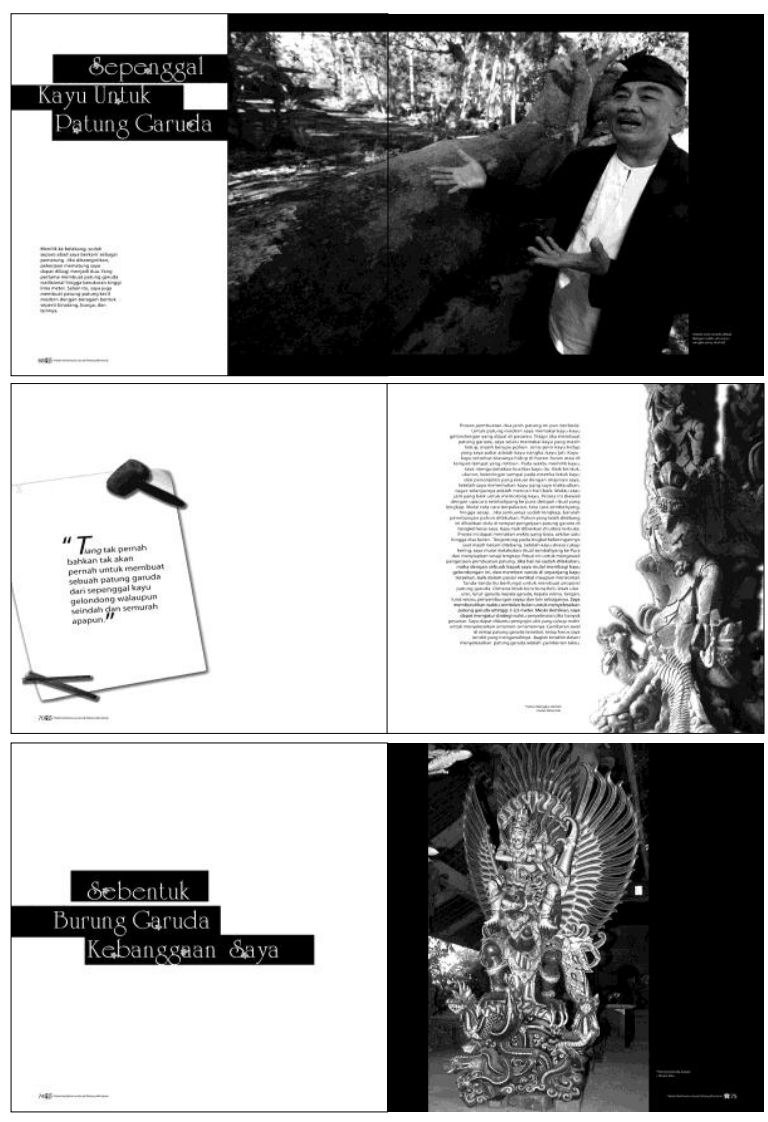

Gambar 3. Halaman isi bagian dua
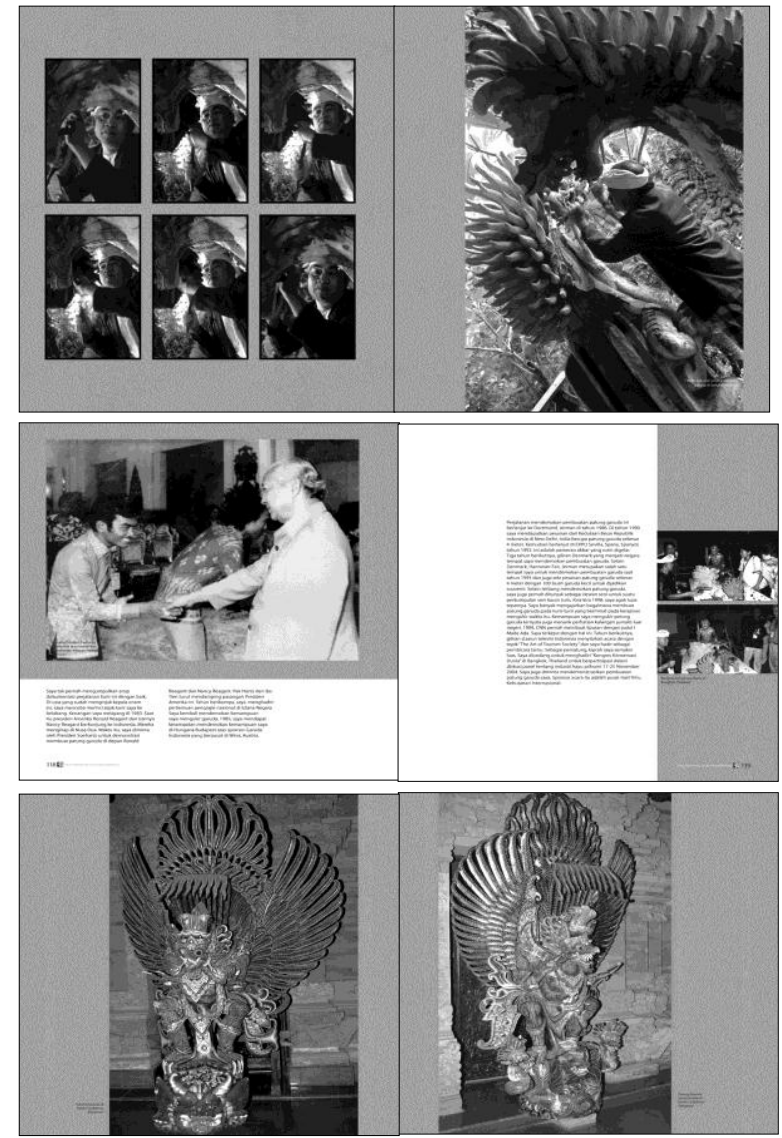

Gambar 4. Halaman isi bagian tiga

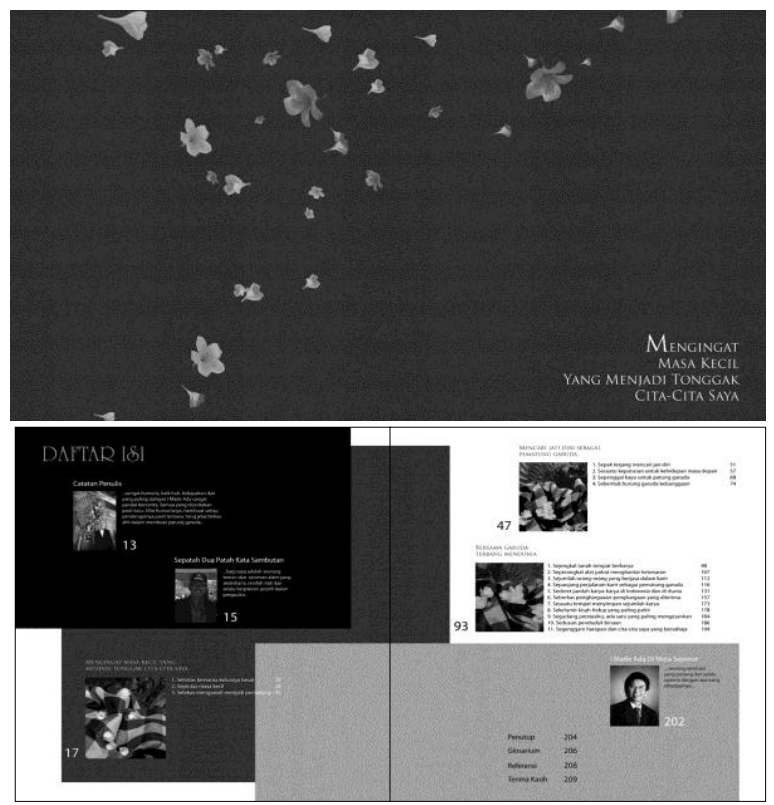

Gambar 5. Penggunaan warna merah maroon

\section{Buku "Made Wianta, Art and Peace"}

Buku ini merupakan buku yang berisi kepedulian Made Wianta terhadap kekerasan. Kepedulian terhadap adanya perdamaian. Kepeduliannya ini dituangkan dalam berbagai macam karya yang 
tergabung menjadi satu karya besar. Didalam buku ini, Made Wianta berkolaborasi lebih dari 2000 seniman lainnya. Karya-karya adalah berupa lukisan, instalasi, tarian dll. Buku ini terbagi atas beberapa bab sesuai dengan jenis-jenis karyanya. Pewarnaan dalam buku kental akan warna hitam dan merah.

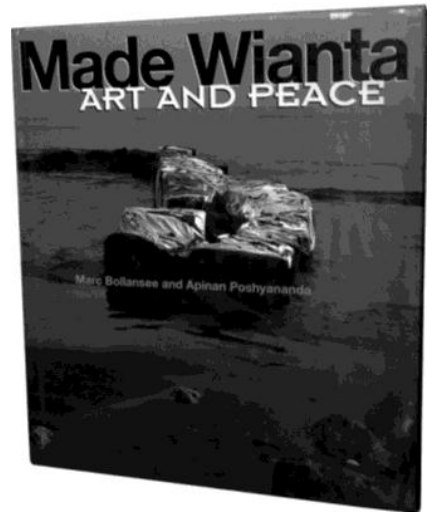

Gambar 6. Cover buku

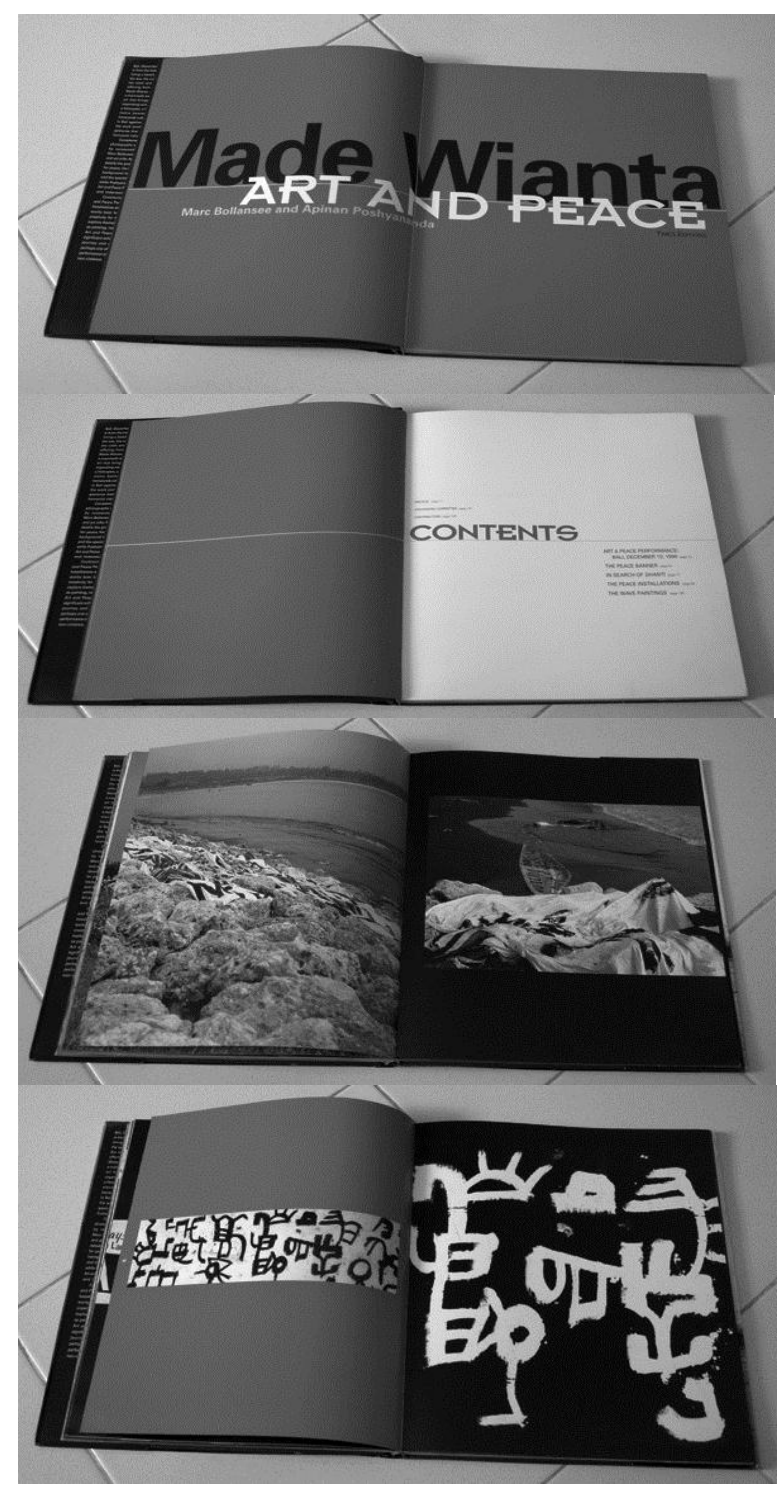

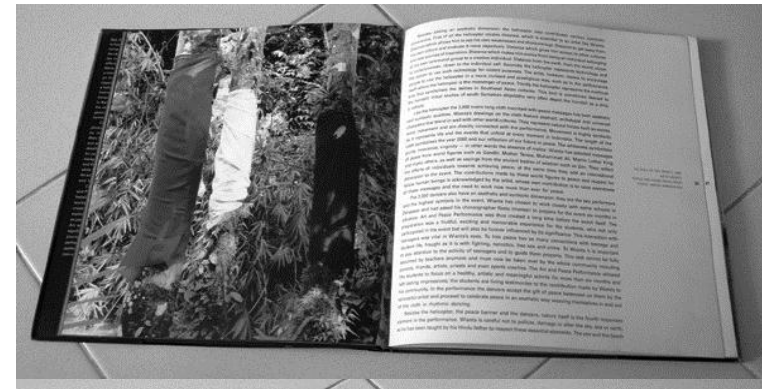

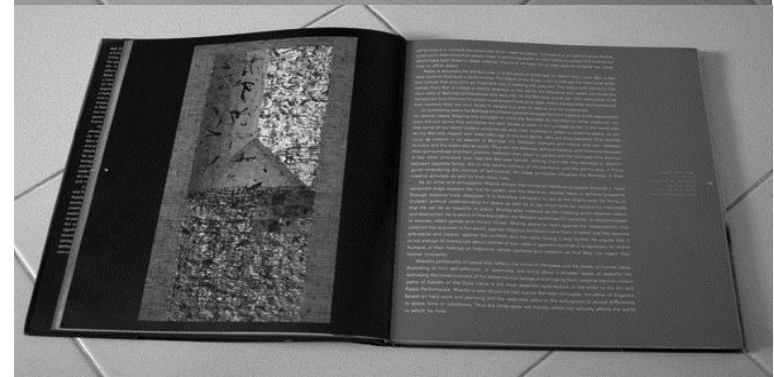

Gambar 7. Halaman isi buku

\section{Buku Made Wianta, Universal Balinese Artist}

Buku ini berisi kumpulan karya-karya Made Wianta dari masa ke masa. Dikumpulkan dan diberi penjelasan berdasarkan jenis karyanya. Karya yang disuguhkan mulai dari lukisan, tulisan, hingga seni instalasi dari Made Wianta. Buku ini kental akan warna merah dan hijau yang cenderung ke arah hitam atau sangat gelap sekali. Buku ini juga menceritakan bagaimana cerita atau riwayat Made Wianta secara singkat oleh si penulis.

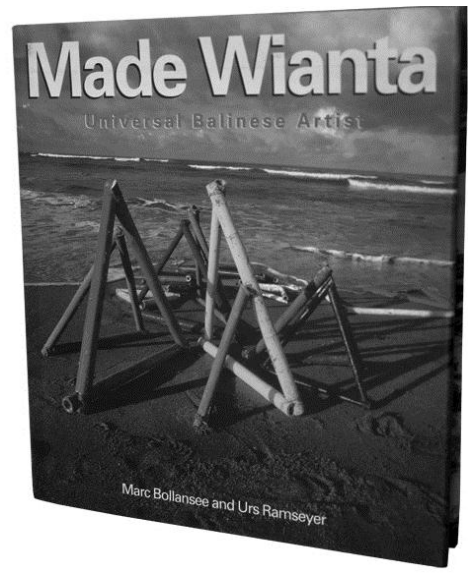

Gambar 8. Cover buku

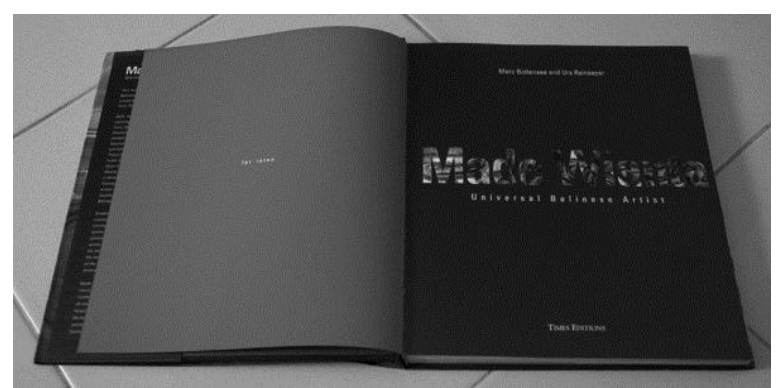




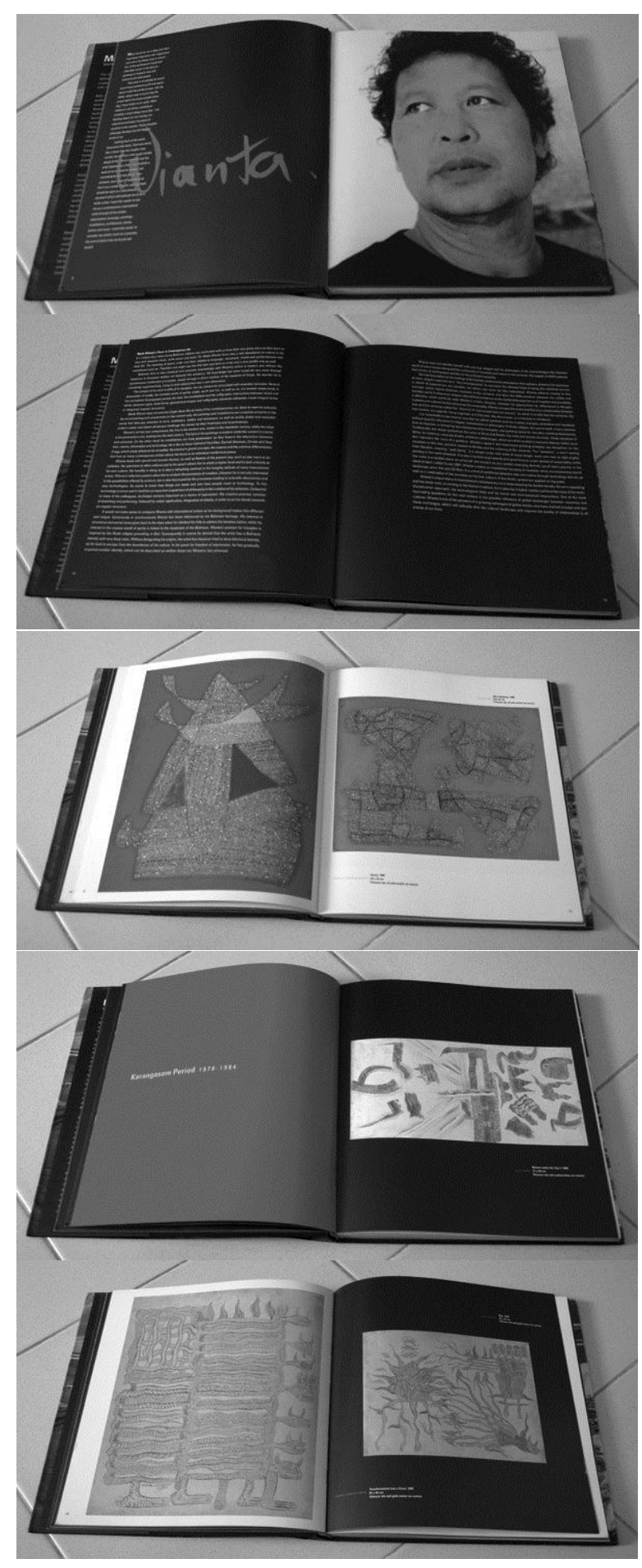

Gambar 9. Halaman isi buku

\section{Pembahasan}

Dalam menjawab permasalahan yang muncul, disini penulis memakai sebuah teori penafsiran yang mengacu pada sebuah teori dasar yang telah ada. Teori penafsiran ini biasanya di sebut dengan pendekatan Hermenutika.

Hermeneutika sebagai sebuah pendekatan mampu mendudukan kita-peneliti didalam masalah yang muncul. Meskipun berawal sebagai pendekatan terhadap kajian teks, namun pada perkembangannya menurut Sumaryono (1999, hal.25) dalam bukunya menyatakan bahwa pendekatan hermeneutika dapat di terapkan di berbagai keilmuan. Hal ini dapat dilihat dari pernyataannya sebagai berikut,

"peralihan dari pengalaman mental ke dalam kata-kata yang diucapkan dan ditulis memupnyai kecenderungan dasar untuk mengerut atau menyempit. Sebuah pengalaman mental atau konsep atau gambaran (image) pada dasarnya kaya akan corak dan warna dan mempunyai nuansa yang beranekaragam. Namun kekayaan alam dan keanekaragaman ini tidak dapt dicakup seluruhnya oleh sebuah kata atau ekspresi (ungkapan) yang membawa makna yang definitive dan khas."

Richard E. Palmer mengatakan dalam Sumaryono (1999, hal.24) bahwa hermeneutika adalah proses perubahan dari tidak tahu menjadi tahu atau mengerti dimana hal ini dapat terjadi dalam pandangan klasik ataupun modern. Sementara menurut Schleiermacher dalam Rahardjo (2008, hal.40) adalah memahami teks lebih baik daripada si pembuat teks itu sendiri. Menurutnya pemahaman ini dilakukan dengan dua cara, yakni dengan menguasai aturan-aturan tentang bahasa si pengarang kemudian penangkapan muatan emosi pengarang dengan cara penempatan penafsir didalam dunia si pengarang.

Sedangkan menurut Pilliang didalam Walker (2010, hal. xix), hermeneutika adalah proses menafsirkan kemungkinan dari suatu objek. Penafsiran ini memiliki sifat yang terbuka, kontekstual dan relatif yang memungkinkan tidak adanya kebenaran yang final.

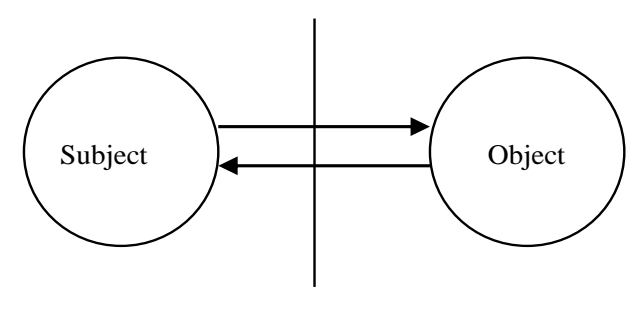

Lingkaran Hermeneutika Interpretasi

Pendekatan hermeneutika ini akan membantu menjabarkan dan menjawab bagaimana sebenarnya pengaruh budaya dalam warna-warna tradisional Bali terhadap penggunaanya oleh beberapa seniman asli Bali dalam karya dan berkaryanya. Warna-warna tradisional Bali ini merupakan sebuah budaya yang ditinggalkan sejak dulu hingga saat ini, dimana warna ini menyatu dalam agama yang mereka yakini. 
Menurut Darmaprawira (2002, hal.156), warnawarna tradisional Bali ini didasarkan pada 3 hal, yaitu fisik, psikis dan supranatural. Falsafah warna-warna ini diduga berasal dari falsafah Hinduisme dari India yang mengalami perkembangan dan perjalanan panjang. Falsafah ini disebut sebagai 'Panca Maha Butha'.

Tabel 1. Penjelasan Nawa Sanga berupa warna, Dewa, dan mata angin masing-masing

\begin{tabular}{lll}
\hline Warna & Dewa & Mata Angin \\
\hline Hitam & Wishnu & Utara \\
Biru & Sambu & Timur Laut \\
$\begin{array}{l}\text { Putih } \\
\text { Jambon }\end{array}$ & Icwara & Timur \\
& $\begin{array}{l}\text { Mahesywara / } \\
\text { Mahisora }\end{array}$ & Tenggara \\
Dadu & Brahma & Selatan \\
Merah muda & Rudra & Barat Daya \\
Kuning & Mahadewa & Barat \\
Hijau & Sangakara / & Barat Laut \\
& Cangkara & \\
$\begin{array}{l}\text { Brumbun/ } \\
\text { pancawarna } \\
\text { (perpaduan warna } \\
\text { penjuru mata } \\
\text { angin) }\end{array}$ & Syiwa / Ciwa & Pusat \\
Singah) & & \\
\hline
\end{tabular}

Sumber: Darmaprawira (2002, hal.157)

Warna-warna tradisional Bali dikatakan mengandung unsur api, air, tanah, udara, dan angkasa. Susunan warna Bali ini disebut dengan nama 'Rajah Nawasanga'. Warna-warna ini terdiri dari Sembilan warna dimana kesemuanya itu dihubungkan dengan arah mata angin dan juga dewa-dewa dalam agama mereka. Nawasanga sendiri diartikan sebagai Sembilan warna atau Sembilan arah mata angin. Biasanya Nawasangan secara visual berupa gambar bunga teratai dan di berikan saat didalam pelajaran agama sejak sekolah dasar.

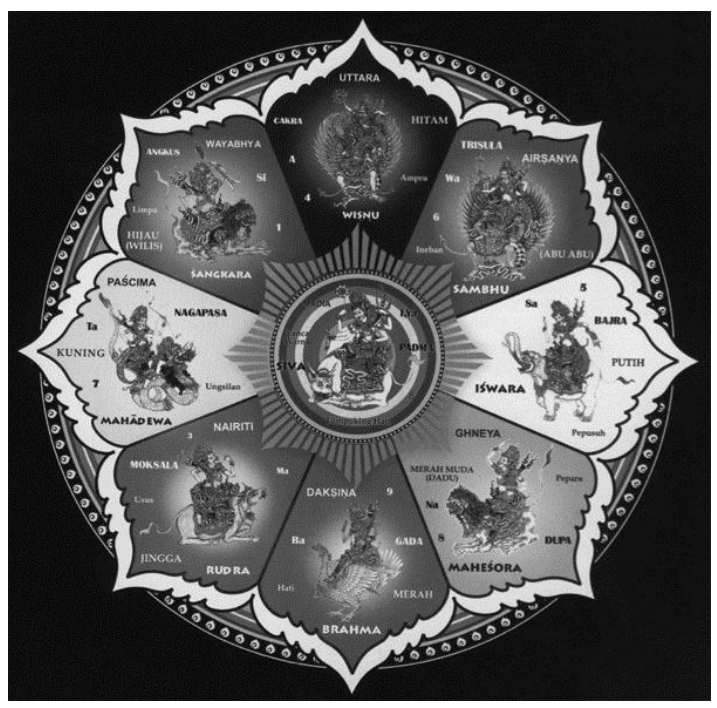

Gambar 10. Gambar Lingkaran Nawasanga
Dalam gambar diatas, isi dan penjelasannya adalah berupa warna-warna tradisional Bali, arah mata angin, nama-nama dewa sesuai dengan warna yang diwakilinya serta senjata-senjata dari dewa-dewa tersebut.

Analisis penggunaan warna tradisional Bali yang sudah dijelaskan tersebut akan di dasarkan pada 3 contoh studi kasus, yaitu Buku Autobiografi I Made Ada dan 2 Buku Made Wianta.

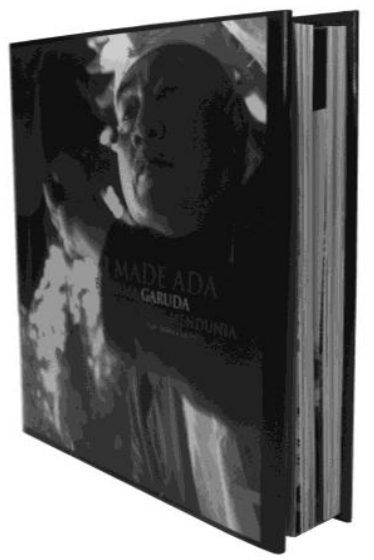

Gambar 11. Buku I Made Ada
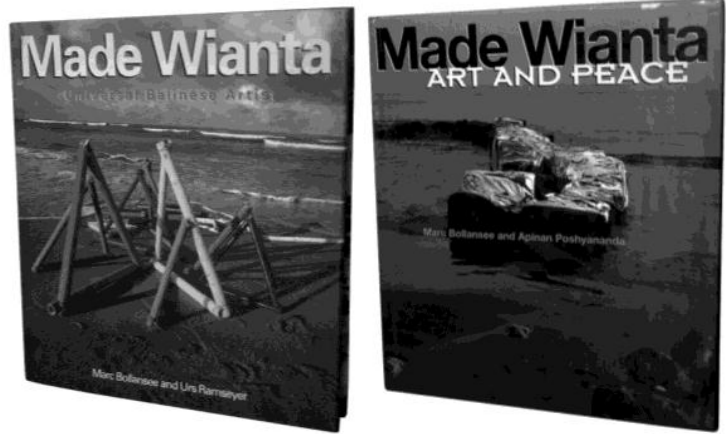

Gambar 12. Buku Made Wianta

Buku autobiografi I Made Ada merupakan sebuah buku yang memberikan kesan gabungan antara modern dan tradisional. Buku ini terbagi menjadi 3 bagian, dimana bagian pertama dan kedua menggunakan warna hitam dan putih sementara bagian ke tiga menggunakan warna emas. Dalam buku ini ada juga pembatas dan halaman yang dianggap penting yang menggunakan warna merah maroon.

"Arts and Peace", merupakan sebuah buku yang, menceritakan kepedulian Made Wianta terhadap adanya kedamaian. Made Wianta menyerukan reaksinya terhadap kekerasan di dunia dengan menghadirkan berbagai karya. Lukisan, seni instalasi, sampai tarian ikut meramaikan aksinya ini dan kesemuanya di rekam ke dalam buku ini. Turut menghadirkan kurang lebih 2000 seniman 
lain dalam tari yang diabadikan lewat foto-foto didalamnya. Buku ini terbagi dalam beberapa bab, sesuai dengan jenis karya yang dibuatnya. Buku ini didominasi dengan warna hitam dan merah, dengan adanya sebuah kejutan kecil yaitu warna kuning.

"Universal Balinese Artist", adalah buku yang berisi karya-karya made Wianta dari masa ke masa. Karya-karya yang berupa lukisan, seni instalasi, juga tulisan kaligrafi dll merupakan dijadikan pembagian untuk setiap babnya sesuai tahunnya juga. Warna yang mendominasi adalah warna merah dengan warna hijau yang cenderung ke arah hitam.

Tiga buku ini menyajikan warna-warna yang cenderung memiliki kesamaan, sama memiliki warna-warna terang namun juga memiliki warnawarna gelap. Dua buku pertama menyajikan warna hitam yang menjadi salah satu dominasi pewarnaan di dalam isinya. Warna hitam di Bali dianggap sebagai warna demikian juga putih. Namun dalam teori warna, kedua warna ini bukanlah sebuah warna. Warna hitam merupakan warna dewa Wisnu. Di Bali sendiri warna hitam yang dipadukan dengan warna putih menjadi sebuah kain poleng yang menjadi ciri khas dari Bali. Dipakai dalam kehidupan sehari-hari seperti pecalang, dan juga di patung-patung yang ada di Bali. Warna hitam dan putih sudah menyatu dalam kehidupan masyarakat Bali. Demikian halnya I Made Ada yang juga menjadikan kedua warna ini menjadi warna dalam pakaian sehariharinya. Hal ini juga terlihat dari foto Made Wianta yang mengenakan kaos hitam, dan juga keahliannya yang disebutkan didalam buku bahwa dia menggambar dalam hitam putih.

Dalam teori warna secara umum, kedua warna ini memiliki arti tersendiri. Hitam dikatakan sebagai warna yang berhubungan dengan sifat-sifat negatif, namun juga bisa dikatakan sebagai pondasi yang kuat. Warna putih adalah kebalikannya, warna putih selalu dikatakan sebagai pihak yang suci, polos dan bersih merupakan hal yang selalu positif.

Warna emas, dalam buku I Made Ada terletak pada bagian ke tiga. Secara umum warna emas dikatakan sebagai warna kejayaan, warna emas diidentikkan dengan sebuah kesuksesan suatu hal. Dalam kehidupan masyarakat Bali sendiri, warna emas selalu hadir disetiap upacara keagamaan dan juga pada kain 'Prada' yang biasanya dipakai sebagai hiasan dan juga pakaian untuk menari dan lainnya. Warna emas juga terlihat menjadi salah satu warna yang banyak digunakan didalam karya-karya patung I Made Ada.

Warna selanjutnya adalah warna merah pada kedua buku Made Wianta. Warna merah ini mendominasi hampir keseluruhan dari buku-buku ini. Dalam kehidupan masyarakat Bali warna ini sering terlihat pada warna-warna dalam upacara keagamaan juga pada karya-karya masyarakat Bali. Warna merah menurut Darmaprawira (2002, hal. 158) merupakan warna yang terkuat, menarik perhatian, agresif, berani, kekuatan, bahaya dll. Warna merah bila dilihat dalam urutan warna di 'Rajah Nawasanga' merupakan warna dari dewa Brahma. Warna yang menjadi dominasi berikutnya dalam buku Made Wianta-"Universal Balinese Artist" adalah warna hijau yang cenderung sangat gelap sekali. Pemakaian warna ini bisa dikaitkan ke arah warna hitam.

Sebagai pemanis ketiga buku ini memiliki warnanya masing-masing. Pertama dalam buku I Made Ada, warna sebagai pemanis tersebut berfungsi sebagai warna yang menarik perhatian, dipusatkan untuk beberapa kejadian penting dan menjadi benang merah di dalam buku tersebut. Warna tersebut adalah warna merah maroon. Warna ini juga terdapat di dalam warna-warna kehidupan masyarakat Bali. Secara umum warna merah maroon, bisa dikaitkan dengan warna merah yang dipandang sebagai kekuatan, menarik perhatian, warna terkuat. Sedangkan untuk warna dalam dua buku Made Wianta, warna dengan fungsi yang sama adalah warna kuning. Warna kuning pun sangat banyak digunakan dalam warnawarna kehidupan masyarakat Bali. Warna kuning dalam ajaran agama Hindu merupakan warna dari Mahadewa. Warna kuning sendiri dipandang secara teori pada umumnya adalah kelincahan dan keceriaan.

\section{Penutup}

Melihat bagaimana warna-warna yang ada di dalam masing-masing buku juga melihat setiap penjelasannya, bagaimana setiap warna yang terpakai selalu memiliki sebuah hubungan dengan warna-warna yang telah menjadi ajaran sejak kecil dan juga telah menyatu dalam kehidupan masyarakat Bali sendiri. Maka dapat disimpulkan bahwa warna-warna ini bukan lagi hanya menjadi teori warna secara umum, namun sudah merupakan sebuah bagian dari hidup setiap orang di Bali. termasuk didalamnya adalah seniman-seniman 
tersebut. Warna-warna tradisional Bali telah terpatri dalam ingatan mereka, meski seiring dengan kemajuan jaman mungkin akan beradaptasi dan menggabungkan antara warna baru dengan warna-warna tradisional tersebut.

Dari temuan-temuan ini, seniman-seniman Bali menaruh warna-warna tersebut bukan lagi hanya sebagai sebuah representasi dirinya yang sebenarnya namun juga ajaran yang telah melekat di dalam dirinya. Bukan lagi bahwa warna-warna ini hanya sebagai pemanis dalam buku yang dibuat tapi menjadi sebuah identitas khusus yang berbeda dilihat secara teori pada umumnya karena berdasar pada pengalaman hidupnya terhadap warna-warna yang menyatu dalam ajaran agamanya.

\section{Daftar Pustaka}

Asthararianty. 2009. Autobiografi I Made Ada, Bersama Garuda Terbang Mendunia. Universitas Kristen Petra. Tidak Diterbitkan.

Bollansee, Marc. Poshyananda, Apinan. 2000. Made Wianta, Art And Peace. Singapore: Times Editions

Darmaprawira W.A., Sulasmi. 2002. Warna, Teori dan Kreativitas Penggunaanya. Edisi ke-2. Bandung: ITB.

Raharjo, Mudjia. 2008. Dasar-Dasar Hermenutika, Antara Intensionalisme \& Gadamerian. Jogjakarta: Ar-ruzz Media.

Sumaryono, E. 1999. Hermenutik, Sebuah Metode Filsafat. Jogjakarta: Kanisius.

Walker. A. John. 2010. Desain, Sejarah, Budaya, Sebuah Pengantar Komprehensif. Jogjakarta: Jalasutra. 